【䫟咬合誌, 13(3)：61～64, 1992】

\title{
ジェットインジェクションテクニックによる
}

新しい印象採得法

\author{
中川 孝男*

\section{A new Impression method} \\ with the Jet Injection technique
}

\author{
Takao Nakagawa*
}

Considering an increasing number of HIV positive and hepatitis patients, it will be required to disinfect impressions of all patients with chemical solution in the future. Therefore silicon impression material will be indispensable in dental practice. However silicon impression incorporates air bubbles more readily than agar material, so that impression taking is considered to be more difficult. The jet injection technique enables an operator, including beginners and inexperienced, to perform precise impression taking of multiple teeth by himself or herself.

\section{はじめに}

今日補緅物の製作は間接法が主流であり，精密印 象がその鍵をにぎっている，精密印象材には，寒天 とシリコーンの 2 種類がある. 前者は口腔内に多少 の水分が存在しても, 精密な印象を採得可能である が, 材料中に約 $80 \%$ の水分を含むため, 印象採得後 の寸法安定性が悪い欠点がある. 後者は親水性不可 重合型シリコーン印象材（以下シリコーン印象材と 略する.)である. シリコーン印象材は経時的な寸法 安定性に優れている。初期の疎水性のシリコーン印 象材では印象の細部再現性が悪く，また石育となじ まないため気泡を生じるといった問題があったが, 親水性のシリコーン印象材の登場によりこうした点 は解決された. シリコーン印象材が最近脚光を浴び るようになった理由としては, 印象採得後に薬液消 毒1を行っても寸法変化を生じないことが挙げられ
る. 寒天印象材は水中に浸した場合膨潤するため薬 液消毒することができないが, シリコーン印象材で は水中に 60 分間浸した後でも $0.05 \%$ の法変化にと どまると報告されている，以下の理由から著者もシ リコーン印象材を日常の臨床に使用している。

従来法のシリコーン印象材の問題点としては, 1) 印象採得のためにアシスタントの助けが必要である. 2) 多数の支台歯を印象する時に失敗する可能性が 高い，3)初心者と熟練者に差ができる４）トレー の固定が悪いと無理な圧接を生じ印象材の変形を生 じ易い。これらの問題点を解決するために著者は ジェットインジェクションテクニックを利用してい る.この方法はパテ状シリコーン印象材でつくった 1 次印象の内面にドレーンを設け, この内部にオー トミックスタイプのシリコーン印象材を注入し印象 面の微細な部分まで印象面を流し込み精密な印象を 採得する方法である。

*東京都渋谷区開業 


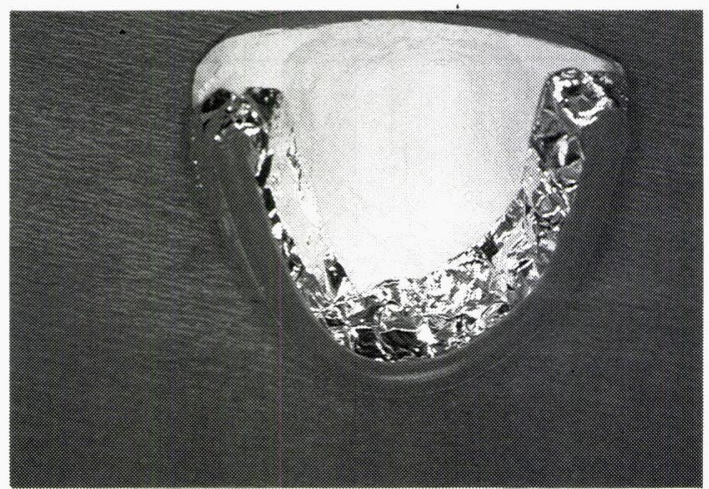

図 1 スタディモデルの歯冠部と歯肉縁に向かって $2 \mathrm{~mm}$ のところまでを 5 枚重ねにしたアルミ䇴で被覆する. そしてアルミ馢で被われた咬合面の中央部に歯列弓に 沿ってユティリティワックスを置きスペーサとする.

\section{臨床術式}

ジェットインジェクション法を用いる時は, 最初 に専用のトレーを製作する必要がある。スタディモ デルを用意し，歯肉縁から $2 \mathrm{~mm}$ のころまでアル ミ䇴を 5 枚重ねにして被覆する. スタディモデルが アルミ馢で被われたら, 咬合面の中央部に歯列弓に 沿ってユティリティワックスを固定する（図1）。 ジェットインジェクションに適したトレーの製法に は2つある. 1つはトレー用の即時重合レジンでカ スタムトレーを各個調整する方法である。このト レーは口腔内にしっかりと固定されるため印象を変 形させる心配がない. しかし石膏の注入後, 印象か ら模型を作り出す際に, トレーを壊さないと模型の

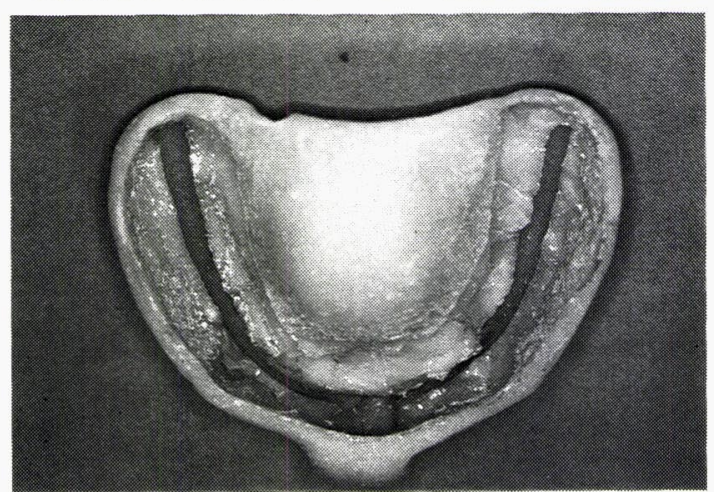

図 2 アルミ箔とユティリティワックスを除去した個人ト レ一の内面。
撤去が困難なことがある。他の 1 つはプラスチック 製の既製トレーとシリコーンパテを組み合わせて使 用する方法である。この方法では技工操作がほとん どないためスピーディにトレーを製作できる利点が ある. 欠点としては既製のトレーを使用するため, トレーのサイズが合わない場合にシリコーンパテの 使用量が多くなり，経済性に久けるということが挙 げられる。

トレーが完成したら内面から，スペーサーとして 使用したアルミ䇴とユティリティワックスを除去す る(図 2 ). 次にトレーの唇側に直径 $5 \mathrm{~mm}$ の穴をあ け，ミキシングチップの差し込みロを設ける。ミキ シングチップの差し込みロと注入口が密接に適合す るように穴あけの操作は慎重に行う必要がある. ミ キシングチップの大きさはメーカーによって違いが あるので, 差し込み口の大きさはミキシングチップ の先端のテパーが半分だけ差し込める大きさが良い. 以上でジェットインジェクション用のトレーが完成 する.

患者を来院させ印象を採得する。個人トレーを即 時重合レジンで製作した場合はトレーの内面にト レー用の接着材を塗布し，エアーシリンジで 3 分間 乾燥する。フィニッシングラインを歯肉縁下に設定 した場合には圧排操作 ${ }^{2)}$ 行う必要がある。圧排用 の綿糸は 2 種類使用する。 まず支台歯の唇側歯頸部 に薬剂の入っていない外科用の縫合系（アンダー コード）を圧入する. 歯肉圧排用綿系の圧入後 5 分 間を経過したら印象採得にうつるが, その直前に

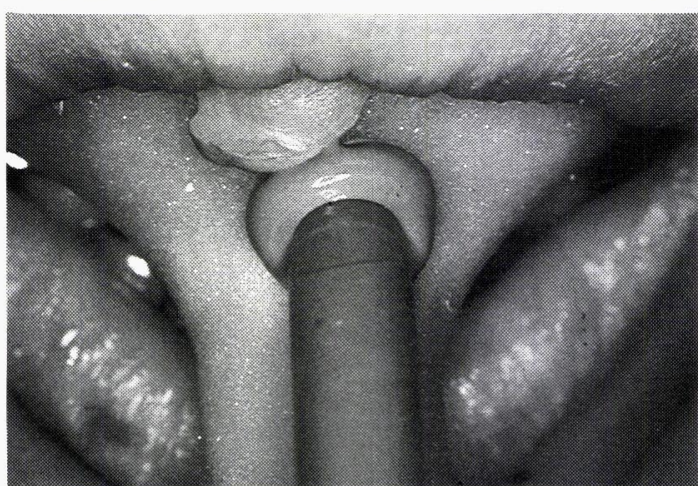

図 3 ミキシングチップを差し込み口に入れ，ガンタイプの ディスペンサーの引き金を引いて, シリコーン印象材 を注入する。個人トレー内のスペースがシリコーン印 象材で満たされると個人トレーは浮き上がる. 
トップコードをはずし，アンダーコードはそのまま 残し印象採得の操作にうつる. 従来の印象に用いら れていたシリンジに，ジェットインジェクションの 場合は細部にまで印象材が入り易いため, フィニッ シングラインが歯肉緑上に形成されている場合には 圧排の必要はない。

トレーを口腔内に固定したらミキシングチップを 差し込み口に入れ，ディスペンサーの引き金を引い て, シリコーン印象材をトレーの中に注入する（図 3 ).ドレインを通って印象材がトレ一の内面に満た されると、トレーがわずかに浮き上がり，辺縁から シリコーン印象材が溢出する。この時点でシリコー ン印象材の注入をやめミキシングチップをトレーか ら抜き取る，浮き上がったトレーをゆっくりと元の 位置にもどしていくと, 差し込み口からシリコーン 印象材が逆流し始める。この位置でそのままトレー を保持する．印象材の硬化後，エアーシリンジで㓌 圧を除去して，トレーを口腔内から撤去する，以上 で印象採得が完了する。なおジェットインジェク ションテクニックでは印象材が印象面のすみずみま で流れ込んでいるためトレーの撒去にやや困難を党 えることがあるかもしれない。㓌圧を除去して着脱 方向を配虑しながらトレーを取りはずすのがポイン トである。

\section{考 察}

従来法では印象面にシリンジを使って印象材を流 した後，印象材を満たしたトレーを所定の位置に㨂 入して印象採得を行った。トレーの挿入時に印象材 に圧力が加わり，Uずみを生ずる危険があった。 ジェットインジェクションテクニックでは, 空のト レーを口腔内の所定の位置に固定した後で, 注入口 から印象材を流し込むためUずみが生じにくい特長 がある。

ジェットインジェクションの原理は国島 (1972) ${ }^{3)}$ が考案した。著者の印象採得法はそれを改良したも のである．国島の方法では口腔内に直接アルミ䈃と ユティリティワックスを压接し，その上からシリ コーンパテでー次印象を採得する。こうして直接口 腔内で一次印象が採得されるため, トレーの挿入時 にユティリティワックスが移動することがある。こ
うした失敗を回避するために著者はスタディモデル 上でトレーを製作することをすすめている.

実験のためにジェットインジェクション用のト レーを透明のレジンで製作し，シリコーン印象材の 流れを観祭した。その結果ミキシングチップから押 し出されるシリコーン印象材の速度とほほ同じ速度 は速くなっている。これは流体力学的には太さの違 うパイプに同じ量の水を流した時に，太いパイプの 中を流れる水の速度は遅いが，細いパイプの中を流 れる水の速度は速くなるという理屈で説明できる。

ジェットインジェクションテクニックを用いた場 合, フルクラウンのような表面被覆性の物体の印象 では良好な結果が得られる。しかしインレーやダウ エルポストのような内面被覆性の物体の印象では, 気泡を埋入させる危険性が高い.グルーブ，ボック 又等の補助的保持形態を付与した場合も同様である。 その理由はアルミ箔で作った薄いスペースからイン レー等の厚いスペースへ移行するために，充分な量 の印象材が補給されないため, 印象材の不足した箇 所が気泡になるためである。前述の説明を使えば, 太いパイプと細いパイプを連結して, 細いパイプか ら水を流した場合太いパイプを水で満たすことはで きないということで理解できるであろう。そのため インレー等の部分はシリンジを使って印象材をまえ もって流し込んでから，ジェットインジェクション で印象を採得することを勄める。

ジェットインジェクションテクニックの利点は次 のようである.1）術者 1 人で印象採得が可能であ る.2）誰にでも失敗なしに多数歯の印象が採得で き，ヒューマンエラーが少ない，3）トレーの圧接 による印象材の変形がない。

\section{おわりに}

HIV ポジティブや肝炎の患者が増加傾向にある ため,これからは全ての症例で採得された印象を㭗 液消毒することが必要になると考之られる。そのた めシリコーン印象材は日常臨床において，不可欠な 材料となると思われる.シリコーン印象材は寒天印 象材よりも気泡を埋入させやすく印象採得は困難と されている。今回紹介したジェットインジェクショ ンテクニックを用いれば初心者熟練者をとわず, 術 
者一人で多数歯の精密な印象採得が可能である.

\section{参考文献}

1) 小田豊, 白鳥八重子, 住井俊夫：ゴム質印象材 の印象採得精度におよぼす消毒剤の影響につい て. 歯科材料・器材, $8: 15,1989$.

2 ) 保母須弥也, 中川孝男：最近ポーセレンラミネー トべニア．医歯薬出版（東京）, 1993.

3 ) 国島康夫：シリコーン印象材の扱い方。歯界展 望, 39：135-147, 1972.

別刷請求先：中川孝男 